\title{
Do as I Say, Not as I Do: The Role of \\ Advice versus Actions in the Decision to Strategically Default
}
Author
Michael J. Seiler

Abstract

\begin{abstract}
In this study, I examine relative private signal strength and find that offered advice is significantly more influential in changing strategic mortgage default proclivity than is observed actions. Moreover, these private signals are more reflective of financial herding than they are of an information cascade. From a policy perspective, herds are easier to reverse than are cascades making more effective policies aimed at curbing the incidence of strategic mortgage default. Interestingly, an informationally equivalent change in private signal strength across actions and advice alters strategic default willingness, but not the moral stance of borrowers, which demonstrates the complexity of this life-altering financially and emotionally impactful decision.
\end{abstract}

According to the theory of social learning, it is rational for individuals to increase their information set through the direct observation of others' behavior (Banerjee, 1992; Bikhchandani, Hirshleifer, and Welch, 1992). However, private signal inferences are not the only way individuals learn (Anderson and Holt, 1997). People also learn through hearing the recommendations of others (Feick and Price, 1987; Bearden, Netemeyer, and Teel, 1989). Whether the context involves the decision to watch a particular movie, eat at a certain restaurant, or adopt a new technology, private signals get conveyed to potential new adopters through both observed actions and advice (Celen and Kariv, 2004; Alevy, Haigh, and List, 2007; Healy, 2009).

In this study, social learning theories are applied to a strategic mortgage default setting. Given that strategic default is a decision reached only after much information gathering and introspection, ${ }^{1}$ it makes for an ideal laboratory to investigate the mechanisms by which private signals/beliefs can be learned from others and if those beliefs can readily be adopted by homeowners considering this life-altering decision. To isolate the relative impact of social learning through the observed action of others versus receiving advice from others, I design an informationally equivalent signal and measure which one has a greater relative impact on a borrower's willingness to strategically default. 
In addition to introducing an informationally equivalent advice versus action private signal, I am also the first to investigate whether the decision to adopt such new information is more reflective of an information cascade or herding. ${ }^{2}$ While the two concepts have been used almost interchangeably in the literature, Smith and Sorensen (2000) explain the critical difference. In an information cascade, individuals ignore private signals and mimic the actions of others. When herding, individuals consider their private signal, but adopt a pattern/behavior consistent with those around them. From a financial stability standpoint, information cascades are harder to break because new, relevant private information is ignored, potentially resulting in the creation of pricing bubbles. Eventually, an information cascade can become more like a herd, and when departures from fundamentals become too great, new and private signals cause some individuals to break from the herd, resulting in a collapse of the pricing bubble. The somewhat immediate return (and likely over reaction) to fundamentals describes the recent housing market crisis (Shiller, 2008).

The contributions of this study are many-fold: (1) By equalizing the private signal strength through the implementation of an experimental design, I am the first to find that homeowners are significantly more likely to adopt a greater willingness to strategically default when exposed to the advice of others more so than when observing the actions of others.

(2) When the advice to either default or not is presented through a professional real estate attorney who has considered the personal financial situation of the homeowner, the ability to alter behavior is of the same magnitude as when the advice is given by borrowers who have previously defaulted and advise the same action. This new contribution is important given that many homeowners reach this critical decision without ever visiting an attorney (see Seiler, Collins, and Fefferman, 2013). (3) While past studies have referenced real estate mavens and their influence on strategic default decision-making, this is the first study to put such a fine point on what it means to be a maven and specifically test the influence of attorney guidance through this legal minefield.

(4) Interestingly, although past studies have linked strategic default proclivity with the borrower's moral stance on the issue, ${ }^{3} \mathrm{I}$ am the first to find that homeowners can differ significantly in their strategic default behavior even though their moral positions remain insignificantly different. This is not to say that morality and strategic default are not correlated, but that far more is considered by borrowers during this complex decision-making process than has been revealed in past studies. (5) Moreover, I vary the probability of lender recourse and find that while proclivity to strategically default changes, the morality viewpoint does not change for the borrower.

(6) Finally, I am the first to identify that the decision to strategically default is more reflective of herding than it is of an information cascade. This is relevant from a policy standpoint in that herds are easier to break than information cascades. So while strategic defaults are on the rise (Wyman, 2010; FICO, 2011; 
Guiso, Sapienza, and Zingales, 2013), it seems entirely possible to reverse this trend through the implementation of new policies intent on curbing this behavior (White, 2010; Wheaton and Nechayev, 2014).

\section{Review of Mortgage Default Literature}

Researchers have long recognized that a put option can be likened to paying on a mortgage (Campbell and Dietrich, 1983; Foster and Van Order, 1984; Epperson, Kau, Keenan, and Muller, 1992; Quigley and Van Order, 1995), where the strike price in the mortgage default model is represented by the outstanding loan balance and the stock price is represented by the home's price. Through this specification, if the time value of the option and the amortization of the loan balance are ignored, ${ }^{4}$ option theory indicates that one would default when the home's price drops below the outstanding balance of the loan. ${ }^{5}$ Several researchers have applied this analogy to create mortgage default models with moderate success (Kau, Keenan, and Kim, 1994; Capozza, Kazarian, and Thompson, 1998).

Studies such as Lekkas, Quigley, and Van Order (1993), Vandell (1995), and Ambrose and Capone (1998) and more recently Foote, Gerardi, and Willen (2008), Bhutta, Dokko, and Shan (2010), and LaCour-Little and Yang (2013) find that most borrowers do not "ruthlessly" default even when faced with prolonged and substantial degrees of negative equity. The authors attribute this decision to traditional utility maximizing explanations such as the transaction costs of terminating a mortgage, an ability to continue paying, and an absence of a triggering event. ${ }^{7}$

In these past studies, utility maximization is defined as a maximization of wealth only. More recently, behavioral studies take a more inclusive view of utility beyond wealth to include the morality of strategic default, how default decisions are viewed by one's social network, among other non-monetary considerations. For example, Seiler (2014) and Seiler and Walden (2014) use inequity aversion theory to demonstrate that the borrower's strategic mortgage default decision is also a function of how they perceive the character of their lender. For example, if their lender has behaved egregiously (e.g., taking government bailout funds and making detrimental subprime loans), borrowers are more willing to exercise their put option as a way to punish lenders for their behavior. ${ }^{8}$

Seiler, Seiler, Lane, and Harrison (2012) allow underwater borrowers to self-select into one of three different pools: strategic defaulters, economic defaulters, or those who remain current on their mortgage payments despite having negative equity. The authors find that ex ante expectations of shame and guilt map consistently with ex post realized levels; however, the realized financial backlash pales in comparison to that which was anticipated. The result is a lack of regret on the part of strategic defaulters whose feet were not held to the fire for their actions. Drivers of strategic default include the future direction of expected home prices, frustration with their lender, moral stance on the issue, gender, and age.

\begin{tabular}{l|l|ll} 
JRER & Vol. 37 & $\mathrm{No} .2-2015$ \\
\hline
\end{tabular}


Interestingly, state-level bankruptcy laws (e.g., personal and home exemption levels) and real estate specific variables (e.g., judicial vs. power-of-sale and recourse vs. non-recourse) were found to have little explanatory power. The authors speculate this could be due to either a lack of understanding exactly how these laws would be applied or maybe that the emotional component of the decision outweighed the economic component.

An extension of the social network idea is presented in Seiler, Collins, and Fefferman (2013). These authors use an infectious disease model and liken advocating strategic mortgage default to the spreading of a traditional virus like the H1N1 flu virus. The cure for the virus is the person advising others not to strategically default. The difference between the live virus model and the social virus is that the live virus can only be spread through physical contact, whereas a social virus can additionally be spread through talking with someone on the phone, hearing a nationally syndicated television or radio show, or any other means that can travel over a distance. This transmission ability of the social virus makes it a potentially more quickly-spreading disease.

The expanse of one's social network, as well as general signal strength on the part of both the sender (real estate experts vs. non-real estate experts) and receiver (susceptibility to normative influence) are considered, but not in anywhere near a level of depth or precision as used in this study.

\section{Methodology and Design}

In a financial marketplace, behavior is observed, but not private signals. This is particularly true in the context of strategic mortgage default where there is no trading space. As a result, when examining the relative private signal strength of competing social learning inputs (advice and actions) for those involved in strategic default, an experimental design must be employed where private signals can be measurably conveyed, as well as where outside influences can be accounted for within the study. Simply put, the decision to strategically default involves input from a number of immeasurable sources and outside influences that in the real world are essentially impossible to quantify. In order to further understand this decision-making process, a more controlled environment is needed where excessive noise can be removed or otherwise controlled.

In order to examine the relative strengths of observed actions versus advice, a data collection instrument is designed to address the research questions. I begin by equalizing the information set of all respondents by sharing fundamental information relating to strategic mortgage default. For example, in the online instrument, there is text on the first screen explaining the primary potential benefits and consequences associated with strategic default. The second screen conveys a specific housing scenario so that all participants consider the decision from the same economic position and while making the same economic assumptions. ${ }^{9}$ Now that everyone is on the same page, the current investigation begins, which is to 
compare and measure the potential ability to alter a borrower's stated willingness to strategically default through the sharing of others' action and/or advice. In all, there are 10 unique treatments, each constructed to isolate a specific aspect of the experimental design. In the initial "Action-only Yes" treatment, the text states:

"We extensively interviewed 1,000 homeowners ${ }^{10}$ across the United States who are in the situation just described to you (roughly $\$ 100,000$ underwater on their mortgage; do not expect home prices to change over the next 4 years; and can just afford to make their mortgage payments). Our goal was to learn of their experiences with general homeownership and their potential strategic mortgage default decisionmaking process.

\section{Of the 1,000 underwater homeowners we interviewed, an overwhelming majority of them HAVE strategically defaulted on their mortgage."}

Respondents are asked how likely they are to strategically default (on an 8-point scale), as well as their opinion of the morality of such an action (also on an 8point scale). In the "Advice-only Yes" treatment, I use an informationally equivalent signal by providing the exact same wording with the only shift being from an observed action to recommended advice as follows:

"We extensively interviewed 1,000 homeowners across the United States who are in the situation just described to you (roughly $\$ 100,000$ underwater on their mortgage; do not expect home prices to change over the next 4 years; and can just afford to make their mortgage payments). Our goal was to learn of their experiences with general homeownership and their potential strategic mortgage default decisionmaking process.

Of the 1,000 underwater homeowners we interviewed, an overwhelming majority of them recommend others SHOULD strategically default on their mortgage."

I first consider the direct potential impact of action versus advice using the first treatments: (1) Action-only Yes; (2) Action-only No; (3) Advice-only Yes; and (4) Advice-only No. ${ }^{11}$ I then consider combined treatments where borrowers' actions may or may not reflect their recommendation to others. For example, an Action and Advice-Yes/No, treatment reads as follows:

"We extensively interviewed 1,000 homeowners across the United States who are in the situation just described to you (roughly $\$ 100,000$ underwater on their mortgage; do not expect home prices to change over the next 4 years; and can just afford to make their mortgage payments). Our goal was to learn of their experiences with general homeownership and their potential strategic mortgage default decisionmaking process. 
Of the 1,000 underwater homeowners we interviewed, an overwhelming majority of those who HAVE strategically defaulted recommend others should NOT strategically default on their mortgage."

This allows those giving advice to reflect upon the outcome of their actions and whether or not that would cause them to recommend others follow suit. The four possible combinations are considered in the scenarios titled: (5) Action and Advice-Yes/No; (6) Action and Advice-No/Yes; (7) Action and Advice-Yes/ Yes; and (8) Action and Advice-No/No. Finally, I conclude with two treatments where a professional real estate attorney who has specifically considered the personal financial situation of the borrower provides a recommendation either for or against default, titled (9) Attorney Advice-Yes; and (10) Attorney AdviceNo. Specifically, the Attorney Advice_-Yes reads:

"We extensively interviewed 100 real estate attorneys across the United States whose clients are in the situation just described to you (roughly $\$ 100,000$ underwater on their mortgage; do not expect home prices to change over the next 4 years; and can just afford to make their mortgage payments). Our goal was to learn of their professional experiences with general homeowners' potential strategic mortgage default decisionmaking process.

Of the 100 real estate attorneys we interviewed, an overwhelming majority of them recommend others SHOULD strategically default on their mortgage."

Consistent with the seminal work of Feick and Price (1987) and Bearden, Netemeyer, and Teel (1989), and more recent results from Engelberg and Parsons (2011) and Seiler, Collins, and Fefferman (2013), I hypothesize that mavens (e.g., expert real estate attorneys) will have a greater ability to influences future decisions than non-mavens (regular homeowners). To examine whether the burgeoning behavior of strategic mortgage default reflects more of an information cascade versus herding, two additional sets of questions are added that are spaced apart in the experimental design. In the first, I ask:

"To help you decide whether or not you should strategically default in this situation, you consult a real estate attorney who specifically looks at the details of your personal financial situation. The attorney shares with you that there is a $[\mathbf{1 0 \%} ; \mathbf{5 0 \%} ; \mathbf{9 0 \%}]$ chance the lender will come after you for the deficiency amount."

The borrower only sees one of the randomly generated numbers inside the brackets $[10 \%, 50 \%$, or $90 \%]$. The borrower is then asked to indicate his willingness to strategically default, as well as his opinion of the morality of such a decision. The comparable question asked later in the experiment is:

"If you defaulted on your mortgage, the lender has a right to come after you for the many months of missed mortgage payments and the 
deficiency amount (i.e., the money you still owe the lender after they sold off your home and tried to pay off the mortgage). What is the probability your lender would come after you to get their money?"

The borrower answers the question on a scale from 1 (Definitely will NOT come after me) to 11 (Definitely will come after me). I then compare the ability to influence this later answer conditional on the randomized treatment presented in the earlier question.

\section{Data}

To investigate the impact of advice and actions on the decision to strategically default, in March of 2013, I collected and analyzed data from 1,539 valid homeowner responses to a total of 10 different experimental treatments (previously described). This "between subjects" data collection effort was carried out using a web-based instrument accessing the same general pool of homeowners from across the country as in Seiler, Seiler, Lane, and Harrison (2012) and Seiler (2014). ${ }^{12}$ Before arriving at a final sample, the data were screened to ensure quality responses. First, I place hidden timers on all pages of the data collection instrument. Because respondents do not know the time spent on each page is being recorded, the data can be screened for participants who sped through the design without fully reading the scenarios/conditions. More directly, two dummy questions are dispersed unevenly through the data collection instrument where the respondent is simply asked to select a number, say "6." Given the nine answer choices, the odds of a person randomly selecting the correct number in both questions is approximately only $1 \%$.

Because the pool of homeowners is accessed through a clearinghouse that keeps records on past performance ratings, a minimum previous approval rating of $95 \%$ is set on all participating homeowners. Those who do not clear this threshold cannot see the posting. Finally, the data collection effort begins when the participant is asked to select their state and city from a pull-down menu. Toward the end of the data collection instrument, the participant is asked for their ZIP Code. Cross-referencing the ZIP Code with the city is another screen to detect those who are completing the instrument using less than accurate information. In sum, a series of screens and other data collection purification techniques are used to ensure as high a sample quality as possible.

\section{Results}

Exhibit 1 reports univariate statistics for the variables included in the regression analyses, as well as basic borrower demographic data. Panel A reports that the likelihood of lender recourse-the belief respondents have concerning the likelihood their lender will pursue a deficiency judgment in the event of strategic default on a scale from 1 (Definitely will NOT come after me) to 11 (Definitely 
borrower blames the lender, the more likely he is to retaliate through strategic mortgage default.

Consumption/Investment Viewpoint measures whether the homeowner views his home as more of an investment (1) or more of a consumption good (9). Homeowners who view their residence as a consumption good live in the home for reasons that go well beyond financial considerations. As a result, even when the home becomes underwater, the homeowner continues to derive positive utility from residency. Alternatively, homeowners who view their home as a pure investment are more likely to strategically default based on their negative equity position, discounting the importance of an emotional attachment to the home. Have You Previously Defaulted? is a dummy variable indicating whether or not the homeowner has ever defaulted on a mortgage. Those who have walked away before are hypothesized to find it easier to walk away again in the future. Moreover, consistent with Seiler, Seiler, Lane, and Harrison (2012), I hypothesize that those borrowers with a previous default found the financial backlash not to be as severe as originally anticipated, which would encourage them to do so again in the future. For those who have previously defaulted, a question appears that asks whether the default was economic or strategic in nature. Demographic variables include whether or not the borrower has a dependent child. I hypothesize that those with dependent children will be more averse to relocating, a reasonably assumed eventual outcome associated with mortgage default. The sign of the remaining demographic variables is left to be determined in an exploratory sense.

The mean likelihood of perceived lender recourse is 7.80 , or around $68 \%$. The mode is $100 \%$, suggesting fear of repercussion as a major deterrent to strategic default. Concerning who is to blame for the financial crisis, the mean score of 4.04 implies homeowners in the sample blame lenders only slightly more than they blame homeowners. Continuing, homeowners in the sample tend to view their home as more of a consumption good (mean $=7.25$ on a 9-point scale). Finally, $6.0 \%$ of the sample had previously defaulted, and of those, $13.2 \%$ were strategic in nature. ${ }^{13}$ Incidentally, $64.8 \%$ of these defaults occurred since 2010. Concerning the demographics of the sample, $55.6 \%$ have at least one dependent child, $47.6 \%$ are male, $66.3 \%$ are married, and $84.9 \%$ are Caucasian. The average age is 38.37 years, and household earnings total around $\$ 70,000$ per annum.

Exhibit 2 reports the results associated with the 10 variants of the experimental design. ${ }^{14}$ The first four rows of Panel A report the ex ante relative influences of the advice-only versus action-only scenarios. The observation of statistical significance between treatments where the advice is yes/no compared to the lack of significance in the action-only yes/no treatments indicate that borrowers are more willing to follow advice rather than mimic the actions of others.

A more direct comparison is made when the ex post treatments reported in Panel $\mathrm{B}$ is considered. The first two rows report the scenarios where (1) those who have strategically defaulted recommend others not strategically default versus (2) those 
Exhibit 2 | Strategic Default and Morality Scores by Advice and Action Categories

\begin{tabular}{|c|c|c|c|c|}
\hline \multirow[b]{2}{*}{ Advice and Action Categories } & \multicolumn{2}{|l|}{ Initial Trials } & \multicolumn{2}{|l|}{ Subsequent Trials } \\
\hline & $\begin{array}{l}\text { Mean Strategic } \\
\text { Default }\end{array}$ & $\begin{array}{l}\text { Mean } \\
\text { Morality }\end{array}$ & $\begin{array}{l}\text { Mean Strategic } \\
\text { Default }\end{array}$ & $\begin{array}{l}\text { Mean } \\
\text { Morality }\end{array}$ \\
\hline \multicolumn{5}{|l|}{ Panel A: Ex ante } \\
\hline Action Only-Yes & 3.41 & 2.94 & 2.95 & 3.04 \\
\hline Action Only-No & 2.98 & 3.20 & 2.85 & 2.89 \\
\hline \multicolumn{5}{|l|}{ Ex ante: Other Combinations } \\
\hline Action Only-Yes & 3.41 & 2.94 & 2.95 & 3.04 \\
\hline Advice Only-Yes & 3.29 & 3.35 & 3.17 & 3.04 \\
\hline Action Only-No & 2.98 & $3.20^{*}$ & 2.85 & 2.89 \\
\hline Advice Only-No & 2.56 & $2.66^{*}$ & 2.71 & 2.94 \\
\hline \multicolumn{5}{|l|}{ Panel B: Ex post } \\
\hline Action $=$ Yes; Advice $=$ No & $2.27^{* *}$ & 2.79 & $2.18^{*}$ & 2.85 \\
\hline Action $=$ No; Advice $=$ Yes & $2.95^{* *}$ & 2.95 & $2.67^{*}$ & 2.70 \\
\hline Action $=$ Yes $;$ Advice $=$ Yes & $3.57^{* * *}$ & 3.22 & $3.67^{* * *}$ & 3.33 \\
\hline Action $=$ No; Advice $=$ No & $2.38^{* * *}$ & 2.99 & $2.72^{* * *}$ & 2.93 \\
\hline \multicolumn{5}{|l|}{ Ex post: Other Combinations } \\
\hline Action $=$ Yes; Advice $=$ No & $2.27^{* * *}$ & 2.79 & $2.18^{* * *}$ & 2.85 \\
\hline Action $=$ Yes; Advice $=$ Yes & $3.57^{* * *}$ & 3.22 & $3.67^{* * *}$ & 3.33 \\
\hline Action $=$ No; Advice $=$ Yes & $2.95^{*}$ & 2.95 & 2.67 & 2.70 \\
\hline Action $=$ No; Advice $=$ No & $2.38^{*}$ & 2.99 & 2.72 & 2.93 \\
\hline Action $=$ Yes; Advice $=$ No & 2.27 & 2.79 & $2.18^{*}$ & 2.85 \\
\hline Action $=$ No; Advice $=$ No & 2.38 & 2.99 & $2.72^{*}$ & 2.93 \\
\hline Action $=$ No; Advice $=$ Yes & $2.95^{*}$ & 2.95 & $2.67^{* * *}$ & $2.70^{*}$ \\
\hline Action $=$ Yes; Advice $=$ Yes & $3.57^{*}$ & 3.22 & $3.67^{* * *}$ & $3.33^{*}$ \\
\hline \multicolumn{5}{|l|}{ Panel C: Ex post professional } \\
\hline Attorney: Advice $=$ Yes & $3.63^{* * *}$ & 3.29 & $3.40^{* * *}$ & $3.08^{*}$ \\
\hline Attorney: Advice $=$ No & $2.47^{* * *}$ & 2.89 & $2.24^{* * *}$ & $2.50^{*}$ \\
\hline
\end{tabular}

Notes: This exhibit reports mean strategic default and morality scores for respondents who were exposed to one of the 10 treatments within the study. The Initial Trials columns refer to cases where the borrow was first presented with one of the 10 treatments of the study, whereas Subsequent Trails refers to the columns where borrowers were first given an attorney's assessment of the likelihood of lender recourse. In Panel A, the sample is restricted to (ex ante) Action only and Advice only trials, whereas Panel B reports results for (ex post) combined Advice and Action trials. Panel $C$ reports trial results where (ex post) advice is given by professional real estate attorneys. Independent Sample $t$-tests reveal levels of significant differences. Before independent sample $t$-tests are performed, a Levine statistic is first computed to make the proper assumption concerning homogeneity of variance.

${ }^{*}$ Indicates statistical significance at the $90 \%$ level.

${ }^{* *}$ Indicates statistical significance at the $95 \%$ level.

${ }^{* * *}$ Indicates statistical significance at the $99 \%$ level. 
who have not defaulted recommending others should strategically default. The advice mean strategic default willingness (2.95) is significantly higher than the action mean willingness (2.27), indicating that borrowers are significantly more willing to follow a recommendation over an observed action of other homeowners.

Several alternative treatment comparisons shed light on the relative strengths of actions versus advice. Consider the first four rows in Panel B of Exhibit 2 under the heading Other Combinations. In the first two rows, the action (yes) is held constant in order to measure the ability to alter borrower willingness to strategically default. The numbers 2.27 and 3.57 are significantly different from each other. Consistently, although not symmetrically, when comparing the action (no) treatments, the numbers 2.95 and 2.38 are also significantly different from each other. In sum, holding actions constant, advice significantly changes willingness to strategically default.

Now consider the reverse analysis in the last four rows of the same section in Exhibit 2. This time, advice is being held constant to examine the impact of observing different actions has on changes in willingness to strategically default. In the advice (no) treatments, there is a lack of statistical significance (2.27 vs. 2.38). In the advice (yes) treatments, significance is only at the $10 \%$ level. In sum, whether comparing directly or indirectly, borrowers are more willing to change their strategic default stance when observing the advice of others over their actions.

Panel $\mathrm{C}$ of Exhibit 2 introduces advice from a real estate attorney who has specifically considered the personal finances of the borrower. Given that many borrowers consult an attorney before defaulting, I consider the influence these mavens have on the decision-making process. Since attorneys have not necessarily gone through the process themselves, but benefit from extensive hindsight through their clients, professional advice is considered to be ex post advice only. As hypothesized, attorneys who advise clients to default significantly alter their stated willingness (3.63 vs. 2.47). Interestingly, this significant difference is roughly equal in disparity to the impact that those who have defaulted and recommend the same have when compared to those who have not defaulted and recommend others should not default either (3.57 vs. 2.38).

What is interesting in Exhibit 2 is that while the 10 treatments produce significantly differential willingness to strategically default, the perceived morality of each decision remains unchanged. Alternatively stated, while statistical significance is observed for strategic default proclivity across the various paired trials, a lack of significance is observed when examining differences in perceived morality of the strategic default decision. This is interesting given that past studies such as Guiso, Sapienza, and Zingales (2013) have reported an extremely high correlation between morality and strategic default. While the two remain correlated in the current investigation as well, the results show that morality and willingness to default do not necessarily go hand in hand. 
To further investigate the influence professional advice has on borrowers' willingness to strategically default, a scenario is created where the homeowner consults a real estate attorney who specifically looks at the details of their personal financial situation. The attorney shares with the borrower that there is a $[10 \%$; $50 \%$; 90\%] chance the lender will pursue them for the deficiency amount. The participant is asked to indicate their willingness to default. Panel A of Exhibit 3 reports the outcomes from trials where the borrower was presented with this scenario first, whereas Panel B reports results for all borrowers who saw this question after seeing one of the 10 advice/action treatments. Consistent with Exhibit 2, the results are separated to control for potential presentation order effects - the possibility that seeing one type of trial might influence the outcome of those that follow.

Consistent with my hypothesis, as the professionally advised probability of lender recourse increases from $10 \%$ to $50 \%$ to $90 \%$, borrower willingness to strategically default decreases from 3.49 to 2.85 to 2.34. An ANOVA indicates statistically significant differences when taken as a group, while post-hoc Tamhane's T2 tests confirm that each of the three pairings of values are significantly different from each other as well. Consistent with the results in Exhibit 2, an ANOVA reveals that morality measures are not significantly different from each other. Thus, the probability of lender recourse is not related to the moral stance borrowers take on strategic default.

\section{Information Cascades versus Herding}

An information cascade is said to exist when a group of people ignore private signals and mimic the behavior of others. An often confused, but distinctly different phenomenon is herding, which is the observation that people behave in a similar fashion. When herding, individuals do not necessarily abandon private signals, but still find it rational to engage in the same activity. While the distinction may seem subtle, it is very important from a financial markets perspective (Smith and Sorensen, 2000). Specifically, because people ignore private signals in an information cascade, the revelation of new information does very little to change group behavior. Alternatively, new and relevant private information can alter the direction of a herd, making herding behavior more fluid and fragile. ${ }^{15}$ In a practical sense, social learning no longer exists inside an information cascade. With this in mind, I next examine whether an information cascade or herding better characterizes the strategic mortgage default decision-making process. If herding exists, borrowers will learn from new private signals. Exhibit 4 reports the results of including such a signal.

As previously discussed, all 1,539 homeowners in the sample were presented with a scenario where they were provided with personalized financial advice from a professional real estate attorney who specializes in advising clients considering strategic mortgage default. Unbeknownst to the homeowner, a probability of lender recourse of $10 \%, 50 \%$, or $90 \%$ was randomly assigned across the three sub- 
Exhibit 3 | Strategic Default and Morality by Attorney-Advised Probability of Lender Recourse

Attorney-Advised Probability of Lender Recourse

\begin{tabular}{|c|c|c|c|c|c|}
\hline \multicolumn{2}{|l|}{$10 \%$} & \multicolumn{2}{|l|}{$50 \%$} & \multicolumn{2}{|l|}{$90 \%$} \\
\hline Strategic & & Strategic & & Strategic & \\
\hline Default & Morality & Default & Morality & Default & Morality \\
\hline
\end{tabular}

Panel A: Borrowers who saw attorney's advice BEFORE seeing one of the 10 treatments

\begin{tabular}{lrrrrrr}
\hline Overall Mean & 3.49 & 3.01 & 2.85 & 2.89 & 2.34 & 2.85 \\
Strategic Default $=1$ & $27.5 \%$ & $36.1 \%$ & $30.8 \%$ & $37.6 \%$ & $45.9 \%$ & $44.0 \%$ \\
Strategic Default $=2$ & $13.0 \%$ & $16.0 \%$ & $21.4 \%$ & $15.8 \%$ & $22.4 \%$ & $10.1 \%$ \\
Strategic Default $=3$ & $18.2 \%$ & $13.8 \%$ & $16.5 \%$ & $13.2 \%$ & $12.3 \%$ & $14.6 \%$ \\
Strategic Default $=4$ & $7.1 \%$ & $10.8 \%$ & $10.9 \%$ & $12.8 \%$ & $3.7 \%$ & $8.6 \%$ \\
Strategic Default $=5$ & $8.6 \%$ & $6.7 \%$ & $8.3 \%$ & $8.3 \%$ & $6.7 \%$ & $8.6 \%$ \\
Strategic Default $=6$ & $14.1 \%$ & $8.2 \%$ & $9.0 \%$ & $4.5 \%$ & $6.7 \%$ & $4.9 \%$ \\
Strategic Default $=7$ & $7.1 \%$ & $2.2 \%$ & $1.5 \%$ & $1.9 \%$ & $0.7 \%$ & $4.1 \%$ \\
Strategic Default $=8$ & $4.5 \%$ & $6.3 \%$ & $1.5 \%$ & $6.0 \%$ & $1.5 \%$ & $5.2 \%$ \\
Sample Size & 269 & 269 & 266 & 266 & 268 & 268 \\
\hline
\end{tabular}

Panel B: Borrowers who saw attorney's advice AFTER seeing one of the 10 treatments

\begin{tabular}{lrrrrrr}
\hline Overall Mean & 3.39 & 3.19 & 2.70 & 2.79 & 1.97 & 2.82 \\
Strategic Default $=1$ & $27.5 \%$ & $29.6 \%$ & $35.4 \%$ & $35.0 \%$ & $57.7 \%$ & $39.4 \%$ \\
Strategic Default $=2$ & $21.9 \%$ & $16.6 \%$ & $22.6 \%$ & $21.8 \%$ & $18.7 \%$ & $17.1 \%$ \\
Strategic Default $=3$ & $8.5 \%$ & $15.8 \%$ & $14.4 \%$ & $12.3 \%$ & $9.3 \%$ & $14.2 \%$ \\
Strategic Default $=4$ & $8.5 \%$ & $14.2 \%$ & $7.8 \%$ & $12.3 \%$ & $4.5 \%$ & $8.9 \%$ \\
Strategic Default $=5$ & $11.3 \%$ & $7.7 \%$ & $10.7 \%$ & $7.0 \%$ & $4.1 \%$ & $6.9 \%$ \\
Strategic Default $=6$ & $9.3 \%$ & $5.7 \%$ & $4.5 \%$ & $5.8 \%$ & $4.1 \%$ & $4.5 \%$ \\
Strategic Default $=7$ & $8.1 \%$ & $4.5 \%$ & $2.1 \%$ & $2.1 \%$ & $1.6 \%$ & $3.3 \%$ \\
Strategic Default $=8$ & $4.9 \%$ & $6.1 \%$ & $2.5 \%$ & $3.7 \%$ & $0.0 \%$ & $5.7 \%$ \\
Sample Size & 247 & 247 & 243 & 243 & 246 & 246 \\
\hline
\end{tabular}

Notes: This exhibit reports mean strategic default and morality scores for respondents who were conveyed various probabilities of lender recourse by an attorney upon strategic default. In Panel A, the sample is restricted to borrowers who saw the attorney advice trials before being presented with one of the 10 treatments, whereas Panel B reports results for those who saw the attorney advice after. ANOVA tests reveal statistically significant differences across probabilities when taken as a group. In Panel A, strategic default: F-statistic $=23.90(p \text {-value }=.000)^{* * *}$; Morality: Fstatistic $=0.419$ ( $p$-value $=.658)$. In Panel B, Strategic Default: F-statistic $=34.41$ ( $p$-value $=$ $.000)^{* * *}$; Morality: F-statistic $=2.933(p$-value $=.054){ }^{*}$

* Indicates statistical significance at the $90 \%$ level.

** Indicates statistical significance at the $95 \%$ level.

*** Indicates statistical significance at the $99 \%$ level. 
Exhibit 4 | Borrower Perceived Probability of Lender Recourse

Attorney-Advised Probability of Lender Recourse

\begin{tabular}{lll}
\hline Overall & $10 \%$ & $50 \%$
\end{tabular}

Panel A: Borrower perceived probability of lender recourse

\begin{tabular}{lrrrr}
\hline Overall & 7.80 & 6.88 & 7.96 & 8.57 \\
Probability $=0 \%$ & $2.7 \%$ & $2.5 \%$ & $2.0 \%$ & $3.5 \%$ \\
Probability $=10 \%$ & $6.5 \%$ & $16.1 \%$ & $2.0 \%$ & $1.4 \%$ \\
Probability $=20 \%$ & $3.2 \%$ & $6.4 \%$ & $1.8 \%$ & $1.6 \%$ \\
Probability $=30 \%$ & $4.4 \%$ & $5.2 \%$ & $4.5 \%$ & $3.5 \%$ \\
Probability $=40 \%$ & $1.8 \%$ & $2.7 \%$ & $1.6 \%$ & $1.0 \%$ \\
Probability $=50 \%$ & $14.8 \%$ & $13.6 \%$ & $20.8 \%$ & $10.1 \%$ \\
Probability $=60 \%$ & $4.7 \%$ & $4.7 \%$ & $6.1 \%$ & $3.5 \%$ \\
Probability $=70 \%$ & $10.7 \%$ & $7.8 \%$ & $14.5 \%$ & $9.7 \%$ \\
Probability $=80 \%$ & $13.6 \%$ & $10.1 \%$ & $14.5 \%$ & $16.3 \%$ \\
Probability $=90 \%$ & $14.7 \%$ & $7.8 \%$ & $9.8 \%$ & $26.5 \%$ \\
Probability $=100 \%$ & $22.9 \%$ & $23.3 \%$ & $22.4 \%$ & $23.0 \%$ \\
Sample Sizes & 1,539 & 516 & 509 & 514 \\
\hline
\end{tabular}

Panel B: Chart of borrower perceived probability of lender recourse

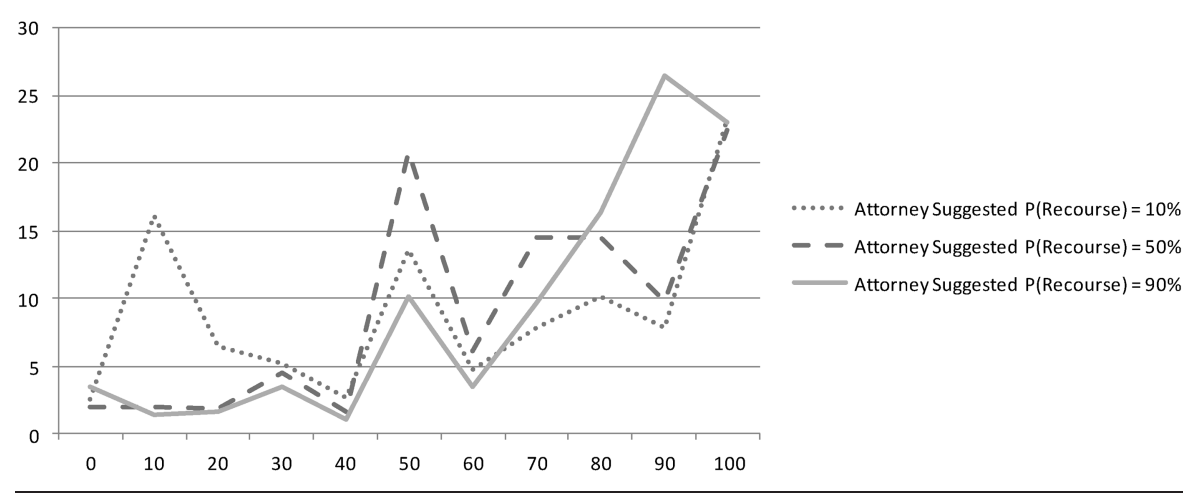

Notes: This exhibit reports the percentage of borrowers who perceive the probability of actual lender recourse conditioned on the probability suggested to them through the attorney advice trial. The overall results are based on a 9-point scale. ANOVA tests reveal statistically significant differences across probabilities when taken as a group. In Panel A, F-statistic $=45.65$ ( $p$-value $=$ .000). ${ }^{* * *}$

*Indicates statistical significance at the $90 \%$ level.

** Indicates statistical significance at the $95 \%$ level.

*** Indicates statistical significance at the $99 \%$ level. 
treatments. In reference to their home, participants were then asked: "If you defaulted on your mortgage, the lender has a right to come after you for the many months of missed mortgage payments and the deficiency amount (i.e., the money you still owe the lender after they sold off your home and tried to pay off the mortgage). What is the probability your lender would come after you to get their money?" As shown in Panel A of Exhibit 4, the overall mean score for all three sub-treatments is 7.80 (on an 11-point scale), which corresponds to a $68 \%$ probability. When segmenting their responses conditional on the previously presented hypothetical scenarios $(10 \%, 50 \%, 90 \%)$, actual perceived probability of lender recourse significantly changes $($ ANOVA $=45.65$, significant at the $99 \%$ level).

A clear demonstration of homeowners' informational learning is seen in the change in responses at each probability level. For example, in the $10 \%$ column, borrower perceptions updated to $16.1 \%$ (as compared with just $2.0 \%$ and $1.4 \%$ for people in the other two treatments). Those originally presented with the randomized $50 \%$ probability of lender recourse in the earlier scenario updated their personalized forward-looking probability of lender recourse belief to $20.8 \%$. This compares to only $13.6 \%$ and $10.1 \%$ for those in the other two sub-treatments. Finally, for the $90 \%$ column, homeowner beliefs were updated to a level of $26.5 \%$ compared with just $14.7 \%$ and $7.8 \%$ for those in the remaining two sub-treatments.

This dramatic convergence between these two measures is best seen graphically in Panel B of Exhibit 4. Only the dotted line (associated with a 10\% attorney suggested probability) spikes at the $10 \%$ perceived lender recourse mark; the dashed line (50\% attorney suggested probability) spikes at the 50\% perceived lender recourse mark; and only the solid line (90\% attorney suggested probability) spikes at the $90 \%$ perceived lender recourse mark. In summary, herding appears to better describe the group behavior as even subtly introduced information is making its way into the borrowers' updated personal belief system. From a policy standpoint, this is important in that strategic default behavior could be altered through the implementation of new policies/information that would economically and emotionally impact the decision-making process.

Thus far, it has been established that borrowers will be more apt to change their stance on strategic mortgage default when receiving advice rather than observing the actions of other homeowners. Moreover, willingness to update beliefs will be stronger when listening to those who have gone through the process before or when advised by a professional real estate attorney who specializes in helping clients through this tumultuous decision. The individual determinants of the decision to strategically default beyond the social learning aspects of hearing advice and observing actions is examined next.

Column (1) in Exhibit 5 includes nine $(n-1)$ of the advice/action treatments. In column (2), four borrower behavior explanatory variables are added to the list of independent variables; while in column (3), borrower demographic variables are included to examine strategic mortgage willingness to default. Although

\begin{tabular}{l|l|lll} 
JRER & Vol. 37 & No. $2-2015$ \\
\hline
\end{tabular}


Exhibit 5 | Strategic Default Proclivity by Advice and Action Categories

\begin{tabular}{|c|c|c|c|c|c|c|}
\hline \multirow[b]{2}{*}{ Variables } & \multicolumn{3}{|c|}{ Strategic Default: Scale } & \multicolumn{3}{|c|}{ Strategic Default: Dummy } \\
\hline & (1) & (2) & (3) & (4) & (5) & (6) \\
\hline Intercept & $\begin{array}{l}3.408 \\
(0.230)^{* * *}\end{array}$ & $\begin{array}{l}5.430 \\
(0.401)^{* * *}\end{array}$ & $\begin{array}{l}6.747 \\
(0.492)^{* * *}\end{array}$ & $\begin{array}{l}-0.672 \\
(0.251)^{* * *}\end{array}$ & $\begin{array}{l}3.919 \\
(0.858)^{* * *}\end{array}$ & $\begin{array}{l}6.127 \\
(1.033)^{* * *}\end{array}$ \\
\hline \multicolumn{7}{|l|}{ Panel A: Experimental blocks } \\
\hline Action Only-No & $\begin{array}{c}-0.433 \\
(0.314)\end{array}$ & $\begin{array}{c}-0.481 \\
(0.300)\end{array}$ & $\begin{array}{c}-0.510 \\
(0.294)^{*}\end{array}$ & $\begin{array}{c}-0.287 \\
(0.351)\end{array}$ & $\begin{array}{c}-0.385 \\
(0.368)\end{array}$ & $\begin{array}{r}-0.445 \\
(0.385)\end{array}$ \\
\hline Advice Only-Yes & $\begin{array}{c}-0.114 \\
(0.318)\end{array}$ & $\begin{array}{c}-0.095 \\
(0.304)\end{array}$ & $\begin{array}{c}-0.172 \\
(0.298)\end{array}$ & $\begin{array}{c}-0.262 \\
(0.355)\end{array}$ & $\begin{array}{c}-0.269 \\
(0.370)\end{array}$ & $\begin{array}{c}-0.358 \\
(0.385)\end{array}$ \\
\hline Advice Only-No & $\begin{array}{l}-0.852 \\
(0.309)^{* * *}\end{array}$ & $\begin{array}{l}-0.890 \\
(0.297)^{* * *}\end{array}$ & $\begin{array}{l}-0.962 \\
(0.291)^{* * *}\end{array}$ & $\begin{array}{l}-0.832 \\
(0.373)^{* *}\end{array}$ & $\begin{array}{l}-0.990 \\
(0.393)^{* *}\end{array}$ & $\begin{array}{l}-1.162 \\
(0.414)^{* * *}\end{array}$ \\
\hline Attorney: Advice $=$ Yes & $\begin{array}{c}0.217 \\
(0.324)\end{array}$ & $\begin{array}{c}0.238 \\
(0.311)\end{array}$ & $\begin{array}{c}0.140 \\
(0.304)\end{array}$ & $\begin{array}{c}0.102 \\
(0.351)\end{array}$ & $\begin{array}{c}0.114 \\
(0.366)\end{array}$ & $\begin{array}{c}0.042 \\
(0.381)\end{array}$ \\
\hline Attorney: Advice $=$ No & $\begin{array}{l}-0.904 \\
(0.334)^{* * *}\end{array}$ & $\begin{array}{l}-0.822 \\
(0.320)^{* * *}\end{array}$ & $\begin{array}{l}-0.821 \\
(0.315)^{* * *}\end{array}$ & $\begin{array}{l}-1.014 \\
(0.426)^{* *}\end{array}$ & $\begin{array}{l}-0.996 \\
(0.445)^{* *}\end{array}$ & $\begin{array}{l}-1.047 \\
(0.462)^{* *}\end{array}$ \\
\hline Action $=$ Yes; Advice $=$ No & $\begin{array}{l}-1.136 \\
(0.332)^{* * *}\end{array}$ & $\begin{array}{l}-1.117 \\
(0.319)^{* * *}\end{array}$ & $\begin{array}{l}-1.132 \\
(0.312)^{* * *}\end{array}$ & $\begin{array}{l}-1.309 \\
(0.453)^{* * *}\end{array}$ & $\begin{array}{l}-1.431 \\
(0.473)^{* * *}\end{array}$ & $\begin{array}{l}-1.475 \\
(0.486)^{* * *}\end{array}$ \\
\hline Action $=$ No; Advice $=$ Yes & $\begin{array}{c}-0.461 \\
(0.320)\end{array}$ & $\begin{array}{c}-0.358 \\
(0.307)\end{array}$ & $\begin{array}{c}-0.415 \\
(0.302)\end{array}$ & $\begin{array}{c}-0.427 \\
(0.365)\end{array}$ & $\begin{array}{c}-0.380 \\
(0.382)\end{array}$ & $\begin{array}{c}-0.399 \\
(0.397)\end{array}$ \\
\hline Action $=$ Yes $;$ Advice $=$ Yes & $\begin{array}{c}0.157 \\
(0.328)\end{array}$ & $\begin{array}{c}0.265 \\
(0.314)\end{array}$ & $\begin{array}{c}0.233 \\
(0.308)\end{array}$ & $\begin{array}{c}0.107 \\
(0.355)\end{array}$ & $\begin{array}{c}0.221 \\
(0.369)\end{array}$ & $\begin{array}{c}0.314 \\
(0.389)\end{array}$ \\
\hline Action $=\mathrm{No}$; Advice $=\mathrm{No}$ & $\begin{array}{l}-1.032 \\
(0.328)^{* * *}\end{array}$ & $\begin{array}{l}-0.947 \\
(0.315)^{* * *}\end{array}$ & $\begin{array}{l}-1.056 \\
(0.309)^{* * *}\end{array}$ & $\begin{array}{l}-1.509 \\
(0.471)^{* * *}\end{array}$ & $\begin{array}{l}-1.494 \\
(0.483)^{* * *}\end{array}$ & $\begin{array}{l}-1.771 \\
(0.507)^{* * *}\end{array}$ \\
\hline
\end{tabular}


Exhibit 5 | (continued)

Strategic Default Proclivity by Advice and Action Categories

\begin{tabular}{|c|c|c|c|c|c|c|}
\hline \multirow[b]{2}{*}{ Variables } & \multicolumn{3}{|c|}{ Strategic Default: Scale } & \multicolumn{3}{|c|}{ Strategic Default: Dummy } \\
\hline & (1) & (2) & (3) & (4) & (5) & (6) \\
\hline \multicolumn{7}{|l|}{ Panel B: Borrower behavior } \\
\hline Perceived Likelihood of Lender Recourse & & $\begin{array}{l}-0.138 \\
(0.024)^{* * *}\end{array}$ & $\begin{array}{l}-0.136 \\
(0.023)^{* * *}\end{array}$ & & $\begin{array}{l}-0.132 \\
(0.030)^{* * *}\end{array}$ & $\begin{array}{l}-0.141 \\
(0.032)^{* * *}\end{array}$ \\
\hline Blame for the Financial Crisis & & $\begin{array}{l}-0.094 \\
(0.037)^{* *}\end{array}$ & $\begin{array}{c}-0.090 \\
(0.036)^{* *}\end{array}$ & & $\begin{array}{l}-0.121 \\
(0.052)^{* *}\end{array}$ & $\begin{array}{c}-0.122 \\
(0.054)^{* *}\end{array}$ \\
\hline Consumption / Investment & & $\begin{array}{l}-0.092 \\
(0.037)^{* *}\end{array}$ & $\begin{array}{c}-0.063 \\
(0.036)^{*}\end{array}$ & & $\begin{array}{c}-0.077 \\
(0.048)\end{array}$ & $\begin{array}{c}-0.046 \\
(0.050)\end{array}$ \\
\hline Previous Default & & $\begin{array}{l}-1.240 \\
(0.298)^{* * *}\end{array}$ & $\begin{array}{l}-1.341 \\
(0.297)^{* * *}\end{array}$ & & $\begin{array}{l}-1.321 \\
(0.345)^{* * *}\end{array}$ & $\begin{array}{l}-1.524 \\
(0.369)^{* * *}\end{array}$ \\
\hline \multicolumn{7}{|l|}{ Panel C: Borrower demographics } \\
\hline Dependent Child Dummy & & & $\begin{array}{c}-0.112 \\
(0.153)\end{array}$ & & & $\begin{array}{c}-0.019 \\
(0.219)\end{array}$ \\
\hline Male Dummy & & & $\begin{array}{c}0.346 \\
(0.138)^{* *}\end{array}$ & & & $\begin{array}{l}0.449 \\
(0.198)^{* *}\end{array}$ \\
\hline Married Dummy & & & $\begin{array}{c}-0.163 \\
(0.170)\end{array}$ & & & $\begin{array}{c}-0.285 \\
(0.237)\end{array}$ \\
\hline Caucasian Dummy & & & $\begin{array}{l}-0.909 \\
(0.193)^{* * *}\end{array}$ & & & $\begin{array}{l}-1.043 \\
(0.251)^{* * *}\end{array}$ \\
\hline
\end{tabular}


Exhibit 5 | (continued)

Strategic Default Proclivity by Advice and Action Categories

\begin{tabular}{|c|c|c|c|c|c|c|}
\hline \multirow[b]{2}{*}{ Variables } & \multicolumn{3}{|c|}{ Strategic Default: Scale } & \multicolumn{3}{|c|}{ Strategic Default: Dummy } \\
\hline & (1) & $(2)$ & (3) & $(4)$ & (5) & (6) \\
\hline \multicolumn{7}{|c|}{ Panel C: Borrower demographics (continued) } \\
\hline Age & & & $\begin{array}{c}-0.011 \\
(0.006)^{*}\end{array}$ & & & $\begin{array}{c}-0.016 \\
(0.009)^{*}\end{array}$ \\
\hline F-statistic & 4.858 & 9.517 & 9.370 & & & \\
\hline$P$-value & 0.000 & 0.000 & 0.000 & & & \\
\hline Adjusted/Pseudo $\mathrm{R}^{2}$ & 0.057 & 0.146 & 0.200 & 0.068 & 0.159 & 0.232 \\
\hline Log Likelihood & & & & 784.60 & 736.05 & 688.58 \\
\hline LR Chi-Square & & & & 34.25 & 82.80 & 122.91 \\
\hline Prob $>$ Chi-Square & & & & 0.000 & 0.000 & 0.000 \\
\hline \multicolumn{7}{|c|}{$\begin{array}{l}\text { Notes: This exhibit presents the results of six regressions explaining the proclivity of respondents to strategically default. Columns (1)-(3) use OLS regressions } \\
\text { to examine the dependent variable, strategic default, on an } 8 \text {-point scale, while columns }(4)-(6) \text { use logistic regression where strategic default has been } \\
\text { converted to a yes / no dummy variable. Previously recorded values of } 1-4 \text { are recoded as } 0 \text {, whereas previously coded vales of } 5-8 \text { are recoded as a } 1 . \\
\text { Panel A contains the nine }(n-1) \text { experimental variants of the design. Panel B adds several borrower behavior explanatory variables, while Panel } C \text { reports } \\
\text { borrower demographics. Note that only borrowers who saw the advice and action trials first are included in this regression. } \\
{ }^{*} \text { Indicates statistical significance at the } 90 \% \text { level. } \\
{ }^{* *} \text { Indicates statistical significance at the } 95 \% \text { level. } \\
{ }^{* * *} \text { Indicates statistical significance at the } 99 \% \text { level. }\end{array}$} \\
\hline
\end{tabular}


previously discussed, I include the nine action/advice treatments as control variables and focus more in Exhibit 5 on Panels B and C. Panel B shows that the perceived probability of lender recourse, placing greater blame on the borrower for the financial crisis (as opposed to the lender), viewing the home as more of a consumption good (as opposed to an investment), and never having previously defaulted all significantly inhibit a willingness to strategically default moving forward. All four of these relations are statistically significant and carry signs consistent with the hypotheses. Panel $\mathrm{C}$ shows that males, minorities, and to a lesser extent younger and lower income borrowers report a greater willingness to strategically default.

In columns (1)-(3) in Exhibit 5, the dependent variable, willingness to strategically default, is measured on an 8-point scale. An alternative metric involves the transformation of willingness to default on a dichotomous scale. Turning the variable into a dummy variable makes practical sense in that a homeowner cannot "somewhat" default. Instead, strategic mortgage default is an all-or-none proposition. ${ }^{16}$ To align the tests with actual decision-making, a rescaling of the yes/no dummy variable is used as the dependent variable in columns (4)-(6). The new dichotomous dependent variable necessitates the implementation of a logistic regression. Otherwise, the analyses follow the same sequential inclusion of independent variables as previously discussed. The results across the six columns are strikingly similar with the exception that the consumption/ investment and income variables fall just outside the level of statistical significance in the logistic regressions.

Exhibit 6 reports the results of an investigation of the profile of those who are more likely to strategically default when advised by a real estate attorney specializing in this critical decision. Panel variables are consistent with prior regression specifications except there is no longer a need to control for the nine $(n-1)$ advice/action treatments since this regression only includes respondents who first saw the legal advice scenario (as opposed to one of the ten advice/action treatments). As before, the sample is restricted to this sub-group to remove unintended presentation order effects that might bias results. Thus, two of the columns are no longer needed.

Panel A of Exhibit 6 displays the probability of lender recourse (this time measured by one of the three evenly spaced probabilities of $10 \%, 50 \%$, or $90 \%$ ). The results show that those who blame homeowners more so than lenders for the financial crisis, those who view their home as more of a consumption good than an investment, and those who have not previously defaulted are statistically significant deterrents to a greater willingness to commit strategic mortgage default. Significant demographic variables include only males. When considering the same variable rescaled as a dummy variable in columns (3) and (4), the results remain robust to specification with the exception that gender is no longer significant. The observation that demographics are not significant indicates the proclivity of homeowners to follow the advice of a real estate professional who offers advice on strategic mortgage default. 
Exhib it 6 | Regression Results explaining Strategic Default Proclivity by Attorney Advised Probability of Lender Recourse

\begin{tabular}{|c|c|c|c|c|}
\hline \multirow[b]{2}{*}{ Variables } & \multicolumn{2}{|c|}{ Strategic Default: Scale } & \multicolumn{2}{|c|}{ Strategic Default: Dummy } \\
\hline & (1) & (2) & (3) & (4) \\
\hline Intercept & $\begin{array}{l}7.652 \\
(0.619)^{* * *}\end{array}$ & $\begin{array}{l}8.254 \\
(0.676)^{* * *}\end{array}$ & $\begin{array}{l}3.396 \\
(0.736)^{* * *}\end{array}$ & $\begin{array}{l}4.171 \\
(0.846)^{* * *}\end{array}$ \\
\hline \multicolumn{5}{|l|}{ Panel A: Borrower behavior } \\
\hline Perceived Likelihood of Lender Recourse & $\begin{array}{l}-0.554 \\
(0.081)^{* * *}\end{array}$ & $\begin{array}{l}-0.561 \\
(0.081)^{* * *}\end{array}$ & $\begin{array}{l}-0.527 \\
(0.109)^{* * *}\end{array}$ & $\begin{array}{l}-0.545 \\
(0.111)^{* * *}\end{array}$ \\
\hline Blame for the Financial Crisis & $\begin{array}{l}-0.192 \\
(0.036)^{* * *}\end{array}$ & $\begin{array}{l}-0.198 \\
(0.036)^{* * *}\end{array}$ & $\begin{array}{l}-0.169 \\
(0.048)^{* * *}\end{array}$ & $\begin{array}{l}-0.182 \\
(0.050)^{* * *}\end{array}$ \\
\hline Consumption/Investment & $\begin{array}{l}-0.090 \\
(0.035)^{* * *}\end{array}$ & $\begin{array}{c}-0.064 \\
(0.035)^{*}\end{array}$ & $\begin{array}{l}-0.121 \\
(0.044)^{* * *}\end{array}$ & $\begin{array}{c}-0.092 \\
(0.045)^{* *}\end{array}$ \\
\hline Previous Default & $\begin{array}{l}-1.138 \\
(0.277)^{* * *}\end{array}$ & $\begin{array}{l}-1.200 \\
(0.279)^{* * *}\end{array}$ & $\begin{array}{l}-1.062 \\
(0.310)^{* * *}\end{array}$ & $\begin{array}{l}-1.156 \\
(0.323)^{* * *}\end{array}$ \\
\hline \multicolumn{5}{|l|}{ Panel B: Borrower demographics } \\
\hline Dependent Child Dummy & & $\begin{array}{c}-0.076 \\
(0.146)\end{array}$ & & $\begin{array}{c}0.054 \\
(0.198)\end{array}$ \\
\hline Male Dummy & & $\begin{array}{c}0.335 \\
(0.137)^{* *}\end{array}$ & & $\begin{array}{c}0.539 \\
(0.185)\end{array}$ \\
\hline Married Dummy & & $\begin{array}{c}-0.194 \\
(0.157)\end{array}$ & & $\begin{array}{c}-0.169 \\
(0.208)\end{array}$ \\
\hline Caucasian Dummy & & $\begin{array}{c}-0.207 \\
(0.184)\end{array}$ & & $\begin{array}{c}-0.376 \\
(0.229)\end{array}$ \\
\hline Age & & $\begin{array}{c}-0.010 \\
(0.006)\end{array}$ & & $\begin{array}{c}-0.120 \\
(0.008)\end{array}$ \\
\hline Income & & $\begin{array}{c}-0.021 \\
(0.046)\end{array}$ & & $\begin{array}{c}-0.040 \\
(0.062)\end{array}$ \\
\hline F-statistic & 26.825 & 12.982 & & \\
\hline$P$-value & 0.000 & 0.000 & & \\
\hline Adjusted/Pseudo R 2 & 0.119 & 0.141 & 0.108 & 0.145 \\
\hline Log Likelihood & & & 814.06 & 789.07 \\
\hline LR Chi-Square & & & 59.41 & 80.96 \\
\hline Prob $>$ Chi-Square & & & 0.000 & 0.000 \\
\hline \multicolumn{5}{|c|}{$\begin{array}{l}\text { Notes: This exhibit presents the results of four regressions explaining the proclivity of borrowers to } \\
\text { strategically default based on the perceived likelihood of default as conveyed through a real estate } \\
\text { attorney. In columns (1) and (2), OLS regressions are used to examine the dependent variable, } \\
\text { strategic default, on an 8-point scale, while in columns (3) and (4), logistic regression are used } \\
\text { where strategic default has been converted to a yes / no dummy variable as previously defined. } \\
\text { Panel A reports results for several borrower behavior explanatory variables, while Panel B reports } \\
\text { borrower demographics. Note that only borrowers who saw the attorney advice trials first are } \\
\text { included in this regression. } \\
{ }^{*} \text { Indicates statistical significance at the } 90 \% \text { level. } \\
{ }^{* *} \text { Indicates statistical significance at the } 95 \% \text { level. } \\
{ }^{* * *} \text { Indicates statistical significance at the } 99 \% \text { level. }\end{array}$} \\
\hline
\end{tabular}




\section{Conclusion}

The decision to strategically default on a mortgage is complex and typically involves a high degree of social learning such as observing the actions taken by others and seeking advice from others. Through a controlled experiment, I am able to hold constant the information content of different private signals and determine that homeowners rely more on the advice of others than they do by purely observing their actions. When differentiating between an information cascade and herding, I introduce a private signal and find that borrowers in the sample do incorporate the private signal into their strategic default decisionmaking process, implying that their behavior reflects that of herding - a rational response to newly revealed information. Herding behavior suggests a greater ability by policymakers to influence the strategic default trend when compared to a cascade because those who herd continue to pay attention to new and relevant information.

When examining who is more likely to strategically default, I find that those who believe the lender will pursue legal recourse, those who place more blame on lenders (as opposed to homeowners) for the financial crisis, those who view their home as more of an investment (as opposed to a consumption good), and those who have defaulted in the past express a greater willingness. Considering individual characteristics, younger borrowers, males, minorities, and lower income borrowers are more likely to default. Interestingly, these borrower demographic variables lose significance when advised by a professional real estate attorney, indicating that a maven's advice is highly valued by borrowers when attempting to navigate the complex strategic mortgage default decision-making process.

One final note of disclosure relates to the generalizability of this study to other fields of real estate. Because the results stem from data collected via an experiment, there will always remain the question of how likely any experimental results are to translate into real world applications of the ideas learned in a study. Since using transactions data is not possible to answer the research questions posed within, there is no way of ever knowing for certain. However, given the aspects of this study that do somewhat overlap with real world observations and extend, somewhat related research efforts, it seems entirely reasonable to accept the findings as being generalizable. They certainly appear as generalizable as other studies that use secondary data to answer their research questions in a world where all else is not held constant during the analysis.

\section{Endnotes}

${ }^{1}$ See studies by Seiler, Seiler, Lane, and Harrison (2012) and Guiso, Sapienza, and Zingales (2013) for a discussion of the involved decision-making process borrowers consider in reference to strategic mortgage default.

${ }^{2}$ We based our approach on Celen and Kariv (2004). 
${ }^{3}$ See studies by Seiler, Seiler, Lane, and Harrison (2012) and Guiso, Sapienza, and Zingales (2013).

${ }^{4}$ Unlike a financial option, a mortgage option is typically associated with a declining strike price (i.e., loan balance) over time. The exception to this statement would be for an interest-only loan or a loan that negatively amortizes such as a graduated payment mortgage.

5 In financial terms, this is known as having "negative equity." In the popular press, this is commonly referred to as being "underwater." For a further discussion, see Seiler, Seiler, Traub, and Harrison (2008), Plaut and Plaut (2010), Zhou and Haurin (2010), Shin, Saginor, and Van Zandt (2011), Zahirovic-Herbert and Chaterjee (2011), Zurada, Levitan, and Guan (2011), MacDonald and Winson-Geideman (2012), and Sun and Seiler (2013).

${ }^{6}$ Ruthless default is defined as a default that occurs the instant negative equity is experienced.

7 Rogers and Winter (2009), Daneshvary, Clauretie, and Kader (2011), Ding, Quercia, Li, and Ratcliffe (2011), An and Qi (2012), Gangel, Seiler, and Collins (2013), and Seiler, Lane, and Harrison (2014) all examine the resulting foreclosure contagion following widespread defaults.

8 This type of behavioral demonstration is in direct opposition to a traditional, more restrictive definition of utility that only considers wealth maximization.

9 Specifically, the statement to the borrower reads: "Imagine you bought your primary residence (the home you own and live in full-time) four years ago at a price of $\$ 300,000$. Since then, the price of your home has dropped dramatically. You are considering strategically defaulting on your mortgage based on the following information." We then ask the borrower to assume the following: "(1) You have a fixed-rate mortgage and can just afford to continue making your mortgage payment, (2) You do not expect the price of your home to change over the next 4 years, and (3) Because of the drop in home prices, if you were to sell your home today and attempt to pay off your mortgage, you would still owe $\$ 100,000$ to your lender."

10 The number 1,000 is chosen simply to reflect a "large number" of interviewed peers. The specific number is not important.

11 To clarify, "actions" refer to what other homeowners have already done, whereas "advice" refers to what they recommend to other people. "Yes" refers to the group advocating strategic default, while "no" indicates the group is against it.

12 To clarify, there are tens of thousands of borrowers in this database. As such, it is unlikely that any of the borrowers in previous studies appear in the current investigation.

13 According to the Mortgage Bankers Association (MBA), current delinquency rates stand at $6.41 \%$ (http://www.housingwire.com/articles/27843-mortgage-delinquency-ratedives-lower-mba); accessed on November 11, 2013. Moreover, Wyman (2010), FICO (2011), and Guiso, Sapienza, and Zingales (2013) report strategic defaults represent from $14 \%$ to $20 \%$ of all defaults. In conclusion, it seems the sample of borrowers is reflective of current market conditions.

14 The Initial Trials column refers to cases when the borrower was first presented with one of the 10 treatments, whereas the Subsequent Trials column refers to when the borrower was first presented with the attorney's assessment of the likelihood of lender default.

15 Banerjee (1992) and Bikhchandani, Hirshleifer, and Welch (1992, 1998) argue this explains fads and bubbles in financial markets. 
16 As such, the values of 1-4 are recoded as 0 , and values of 5-8 as a one. This specification results in roughly $77 \%$ of the sample electing not to strategically default.

\section{References}

Alevy, J., M. Haigh, and J. List. Information Cascades: Evidence from a Field Experiment with Financial Market Professionals. Journal of Finance, 2007, 62:1, 151-80.

Ambrose, B. and C. Capone. Modeling the Conditional Probability of Foreclosure in the Context of Single-Family Mortgage Default Resolutions. Real Estate Economics, 1998, 26: 3, 391-429.

An, M. and Z. Qi. Competing Risk Models using Mortgage Duration Data under the Proportional Hazard Assumption. Journal of Real Estate Research, 2012, 34:1, 1-26.

Anderson, L. and C. Holt. Information Cascades in the Laboratory. American Economic Review, 1997, 87:5, 847-62.

Banerjee, A. A Simple Model of Herd Behavior. Quarterly Journal of Economics, 1992, 107:3, 797-817.

Bearden, W., R. Netemeyer, and J. Teel. Measurement of Consumer Susceptibility to Interpersonal Influence. Journal of Consumer Research, 1989, 15:4, 473-81.

Bhutta, N., J. Dokko, and H. Shan. The Depth of Negative Equity and Mortgage Default Decisions. Working Paper, Federal Reserve Board of Governors, 2010.

Bikhchandani, S., D. Hirshleifer, and I. Welch. A Theory of Fads, Fashion, Custom, and Cultural Change as Informational Cascades. Journal of Political Economy, 1992, 100:5, 992-1026.

Bikhchandani, S., D. Hirshleifer, and I. Welch. Learning From the Behavior of Others: Conformity, Fads, and Informational Cascades. Journal of Economic Perspectives, 1998, $12: 3,151-70$.

Campbell, T. and J. Dietrich. The Determinants of Default on Insured Conventional Residential Mortgage Loans. Journal of Finance, 1983, 38:5, 1569-81.

Capozza, D., D. Kazarian, and T. Thomson. The Conditional Probability of Mortgage Default. Real Estate Economics, 1998, 26:3, 259-89.

Celen, B. and S. Kariv. Distinguishing Informational Cascades from Herd Behavior in the Laboratory. American Economic Review, 2004, 94:3, 484-97.

Daneshvary, N., T. Clauretie, and A. Kader. Short-Term Own-Price and Spillover Effects of Distressed Residential Properties: The Case of a Housing Crash. Journal of Real Estate Research, 2011, 33:2, 179-206.

Ding, L., R. Quercia, W. Li, and J. Ratcliffe. Risky Borrowers or Risky Mortgages Disaggregating Effects Using Propensity Score Models. Journal of Real Estate Research, 2011, 33:2, 245-77.

Engelberg, J. and C. Parsons. The Causal Impact of Media in Financial Markets. Journal of Finance, 2011, 66:1, 67-97.

Epperson, J., J. Kau, D. Keenan, and I. Muller. A Generalized Valuation Model for FixedRate Residential Mortgages. Journal of Money, Credit and Banking, 1992, 24:3, 279-99.

Feick, L. and L. Price. The Market Maven: A Diffuser of Marketplace Information. Journal of Marketing, 1987, 51:1, 83-97.

FICO. Predicting Strategic Default. White paper, April 2001.

\begin{tabular}{l|l|lll} 
J R E R & Vol. 37 & $\mathrm{~N} \circ .2-2015$ \\
\hline
\end{tabular}


Foote, C., K. Gerardi, and P. Willen. Negative Equity and Foreclosure: Theory and Evidence. Journal of Urban Economics, 2008, 64:2, 234-45.

Foster, C. and R. Van Order. An Option-Based Model of Mortgage Default. Housing Finance Review, 1984, 3:4, 351-72.

Gangel, M., M. Seiler, and A. Collins. Exploring the Foreclosure Contagion Effect Using Agent-Based Modeling. Journal of Real Estate Finance and Economics, 2013, 46:2, 33954.

Guiso, L., P. Sapienza, and L. Zingales. The Determinants of Attitudes Towards Strategic Default on Mortgages. Journal of Finance, 2013, 68:4, 1473-1515.

Healy, A. How Effectively Do People Learn from a Variety of Different Opinions? Experimental Economics, 2009, 12:4, 386-416.

Kau, J., D. Keenan, and T. Kim. Transaction Costs, Suboptimal Termination and Default Probabilities. Real Estate Economics, 1993, 21:3, 247-63.

LaCour-Little, M. and J. Yang. Taking the Lie Out of Liar Loans: The Effect of Reduced Documentation on the Performance and Pricing of Alt-A and Subprime Mortgages. Journal of Real Estate Research, 2013, 35:4, 507-53.

Lekkas, V., J. Quigley, and R. Van Order. Loan Loss Severity and Optimal Mortgage Default. Real Estate Economics, 1993, 21:4, 353-71.

MacDonald, D. and K. Winson-Geideman. Residential Mortgage Selection, Inflation Uncertainty, and Real Payment Tilt. Journal of Real Estate Research, 2012, 34:1, 51-71. Plaut, O. and S. Plaut. Decisions to Renovate and to Move. Journal of Real Estate Research, 2010, 32:4, 461-84.

Quigley, J. and R. Van Order. Explicit Tests of Contingent Claims Models of Mortgage Default. Journal of Real Estate Finance and Economics, 1995, 11:2, 99-117.

Rogers, W. and W. Winter. The Impact of Foreclosures on Neighboring Housing Sales. Journal of Real Estate Research, 2009, 31:4, 455-79.

Seiler, M. The Effect of Perceived Lender Characteristics and Market Conditions on Strategic Mortgage Defaults. Journal of Real Estate Finance and Economics, 2014, 48:2, 256-70.

Seiler, M., A. Collins, and N. Fefferman. Strategic Mortgage Default in the Context of a Social Network: An Epidemiological Approach. Journal of Real Estate Research, 2013, $35: 4,445-75$.

Seiler, M., M. Lane, and D. Harrison. Mimetic Herding Behavior and the Decision to Strategically Default, Journal of Real Estate Finance and Economics, 2014, 49:4, 621-53.

Seiler, M., V. Seiler, M. Lane, and D. Harrison. Fear, Shame, and Guilt: Economic and Behavioral Motivations for Strategic Default. Real Estate Economics, 2012, 40:S1, 199_ 233.

Seiler, M., V. Seiler, S. Traub, and D. Harrison. Regret Aversion and False Reference Points in Residential Real Estate. Journal of Real Estate Research, 2008, 30:4, 461-74.

Seiler, M. and E. Walden. Lender Characteristics and the Neurological Reasons for Strategic Mortgage Default. Journal of Real Estate Research, 2014, 36:3, 341-62.

Shiller, R. How a Bubble Stayed under the Radar, 2008. http://www.nytimes.com/2008/ 03/02/business/02view.html. Accessed on November 12, 2013.

Shin, W., J. Saginor, and S. Van Zandt. Evaluating Subdivision Characteristics on SingleFamily Housing Values Using Hierarchical Linear Modeling. Journal of Real Estate Research, 2011, 33:3, 317-48. 
Smith, L. and P. Sorensen., Pathological Outcomes of Observational Learning. Econometrica, 2000, 68:2, 371-98.

Sun, H. and M. Seiler. Hyperbolic Discounting, Reference Dependence and its Implications for the Housing Market. Journal of Real Estate Research, 2013, 35:1, 1-23.

Vandell, K. How Ruthless is Mortgage Default? A Review and Synthesis of the Evidence. Journal of Housing Research, 1995, 6:2, 245-64.

Wheaton, W. and G. Nechayev. Rebalancing the U.S. Housing Market: Two Proposals. Working paper, MIT, 2014.

White, B. Underwater and Not Walking Away: Shame, Fear, and the Social Management of the Housing Crisis. Wake Forest Law Review, 2010, 45, 971-1023.

Wyman, O. Understanding Strategic Default in Mortgages. Experian Report, 2010.

Zahirovic-Herbert, V. and S. Chaterjee. What is the Value of a Name? Conspicuous Consumption and House Prices. Journal of Real Estate Research, 2011, 33:1, 105-25.

Zhou, Y. and D. Haurin. On the Determinants of House Value Volatility. Journal of Real Estate Research, 2010, 32:4, 377-95.

Zurada, J., A. Levitan, and J. Guan. A Comparison of Regression and Artificial Intelligence Methods in a Mass Appraisal Context. Journal of Real Estate Research, 2011, 33:3, 34987.

Michael J. Seiler, William \& Mary, Williamsburg, VA 23187-8795 or Michael.Seiler@ mason.wm.edu. 
Reproduced with permission of the copyright owner. Further reproduction prohibited without permission. 